\title{
Modelling the Drying Characteristics of Osmosised Coconut Strips at Constant Air Temperature
}

\section{Agarry SE* and Aworanti OA}

Biochemical Engineering and Biotechnology Research Laboratory, Department of Chemical Engineering, Ladoke Akintola University of Technology, Ogbomoso, Nigeria

\begin{abstract}
Drying was performed on osmotically dehydrated coconut meat. The coconut was osmotically pre-treated using three different concentrations of sucrose solutions and immersed in a temperature water bath for $3 \mathrm{~h}$ at temperatures of 30,40 and $50^{\circ} \mathrm{C}$, respectively. The osmosised and non-osmosised (control) coconut strip samples were dried in an oven at a drying temperature of $60^{\circ} \mathrm{C}$. The results showed that drying regime was characteristically in the falling rate period. A regression analysis was used to fit three thin layer drying models to the experimental drying data. The most appropriate model(s) was selected using correlation coefficient $\left(\mathrm{R}^{2}\right)$ and root mean square error (RMSE). The page model showed a better fit of the experimental drying data (as compared to other models) on the basis that $R^{2}>$ 0.99 and RMSE $<0.0130$. The effects of the osmotic pre-treatment on the drying data of coconut samples were also explained. The effective moisture diffusivity ranged from 5.74 to $7.88 \times 10^{-10} \mathrm{~m}^{2} / \mathrm{s}$ for osmosised coconut sample and $5.44 \times 10^{-10} \mathrm{~m}^{2} / \mathrm{s}$ for non-osmosised coconut sample.
\end{abstract}

Keywords: Coconut; Osmotic dehydration; Drying; Effective diffusivity; Water content; Drying models

\section{Introduction}

Drying is one of the oldest processes used in the preservation of cultural food products. It is gaining attention as one of the emerging technology which requires innovations for research studies. Drying is dependent on two fundamental principles (i.e. heat and mass transfer). Firstly, heat has to be transferred to the product and secondly moisture has to be removed from the product [1]. Since drying is an energy driven unit operation, its efficiency can be improved if the drying rate that determines the drying period is increased. Long drying periods may lead to poor quality of final products $[1,2]$. Conditions which result in higher drying rates are sought for giving rise to acceptable final products that are economically and nutritionally viable [1].

It is on this basis that physical pretreatments such as osmotic pretreatment have been investigated in order to improve drying kinetics or product quality [3-6]. The beneficial effect of osmotic pretreatment includes higher quality of the final product and lower energy requirements $[7,8]$. Several factors affecting this treatment process include the type and concentration of the osmotic solutions, processing temperature and time, rate of agitation and raw material characteristics [9]. However, extensive studies have not been done on the effect of osmotic process variables on the drying behavior of food materials.

Notable workers who have studied the effect of osmotic solution concentrations on the drying characteristics of food materials include Karathanos and Kostaroproulos [5], Nieto et al. [10], Madamba [6] and Garcia et al. [11]. However, no relevant information has been provided on this subject (osmotic air-drying) except that the concentrations of osmotic solution have been observed to affect the drying properties of agricultural produce [6]. Specifically, that of coconut has not been studied. Also, many studies have emphasized drying kinetics and thinlayer drying models for fruits and vegetables such as organic apple slices [12], carrots [13], rose hips [14], raw mango slices [10,15], young coconut and chopped coconut $[6,16,17]$. Nonetheless, the preceding thin-layer drying models provided no data for drying of osmotically pretreated coconut chips or strips.
Coconut (Cocos nucifera L.) being one of the most important crops in the tropical countries and grown in more than 80 countries of the world with a total production of 61 millions tonnes per year [18]. Nigeria produced 1088500 million tonnes of coconut palm between 2004 and 2008 [19]. Coconut can be consumed in various types of coconut derived products - coconut milk, coconut juice, coconut flour, coconut oil, and desiccated coconut [17]. The desiccated coconut with very low moisture content of about $3 \%$ dry weight basis can be use for the decoration of ice cream, cake, donuts and as flavoring agent in chocolate bars, sweets and biscuits $[17,18]$.

Therefore, the objective of this work is to study the effect of osmotic solution concentration and its operating temperature (pretreatment variables) on the air drying properties of coconut and to fit some thinlayer drying models in which the drying rate constants and model coefficients rely on the osmotic pretreatment conditions or variables.

\section{Materials and Methods}

\section{Materials}

The coconut used for this study was obtained from a local city market of Ogbomoso in Oyo state, Nigeria. The coconut was broken up and the meat was removed, washed and cleaned after which it was cut (using vegetable shredder) into thick strips of regular rectangular shape $(6.0 \times 3.0 \times 0.5 \mathrm{~cm})$ with nearly $1.0 \mathrm{~cm}$ thickness. Sugar (sucrose) with trade mark ST LOUIS Sucre, France, bought from local supermarket in Ogbomoso was used as the osmotic agent (solute) for the osmotic

*Corresponding author: Agarry SE, Biochemical Engineering and Biotechnology Research Laboratory, Department of Chemical Engineering, Ladoke Akintola University of Technology, Ogbomoso, Nigeria, E-mail: sam_agarry@yahoo.com

Received February 24, 2012; Accepted March 21, 2012; Published March 23 2012

Citation: Agarry SE, Aworanti OA (2012) Modelling the Drying Characteristics of Osmosised Coconut Strips at Constant Air Temperature. J Food Process Technol 3:151. doi:10.4172/2157-7110.1000151

Copyright: (C) 2012 Agarry SE, et al. This is an open-access article distributed under the terms of the Creative Commons Attribution License, which permits unrestricted use, distribution, and reproduction in any medium, provided the original author and source are credited. 
pretreatment. The other materials that were used in this study include electric oven, temperature controlled water bath, electronic weighing balance and beakers.

\section{Methods}

Osmotic dehydration: $30 \mathrm{~g}$ of coconut meat chips were placed in three different $250 \mathrm{ml}$ beakers containing sucrose solution of concentration 40,50 and $60 \% \mathrm{w} / \mathrm{w}$, respectively. The beakers were then placed in a temperature controlled water bath (DK-420 Glufex Medical and Scientific, England) maintained at $30^{\circ} \mathrm{C}$ for 3 hours. Thereafter, the osmotic dehydrated samples (coconut samples) were removed and the excess solution on the surface of samples was removed with absorbent paper and then re-weighed. These procedures were repeated with a constant sucrose solution concentration of $40 \%$ w/w at 40 and $50^{\circ} \mathrm{C}$. The weight reduction (WR), sugar gain (SG) and the water content loss (WL) of coconut meat samples was respectively calculated using Equations (1) to (3) [7]:

$$
\begin{aligned}
\mathrm{WR} & =\frac{M_{f}-M_{o}}{M_{o}} \\
\mathrm{SG} & =\frac{m_{f}-m_{o}}{M_{o}} \\
\mathrm{WL} & =\frac{\left(M_{o}-m_{o}\right)-\left(M_{f}-m_{f}\right)}{M_{o}}
\end{aligned}
$$

Where: $M_{0}$ is initial weight of fresh coconut before osmotic treatment $(\mathrm{g}) ; M_{\rho}$ final weight of coconut after time $t$ of osmotic treatment $(\mathrm{g}) ; M_{0}$, dry weight of fresh coconut $(\mathrm{g}) ; M_{\rho}$ final dry weight of coconut after time $t$ of osmotic treatment $(\mathrm{g})$.

Oven drying: Drying experiments were carried out in an oven dryer (Uniscope SM 9053A, England). The dimensions of the dryer are $0.693 \times 0.470 \times 0.486 \mathrm{~m}$. The dryer consisted of a tray, electrical heater, fan and a temperature controller $\left(50-200^{\circ} \mathrm{C}\right.$, dry bulb temperature). The osmotically pretreated coconut meat samples were charged into the dryer and drying was performed at a dry bulb temperature of $60^{\circ} \mathrm{C}$. At regular time intervals of 60 minutes, the samples were withdrawn for weight measurement. The total drying time was obtained as the time required for the sample to attain a constant weight (or bone dry weight). Drying rates for each pretreatment condition were estimated based on weight of water removed per unit time and per kilogram of dry matter $\left(\mathrm{kg} \mathrm{kg}^{-1} \mathrm{~h}^{-1}\right)[20,21]$. The moisture contents of both the fresh and dried samples were determined according to AOAC [22].

Drying parameter estimation: Thin-layer mathematical drying models describe the drying phenomenon in a unified way regardless of the controlling mechanisms $[23,24]$. In thin layer drying, the moisture ratio during drying is calculated as follows:

$$
\mathrm{MR}=\frac{M-M_{e}}{M_{o}-M_{e}}
$$

Where MR is the moisture ratio, $\mathrm{M}$ is the moisture content at any time, $M_{0}$, the initial moisture content, and $M_{e}$, the equilibrium moisture content respectively, on dry weight basis.

During thin layer drying of coconut, the samples were not exposed to uniform relative humidity and temperature continuously. As a result of this, the equilibrium moisture content could not be determined and since this is usually not high for food materials $[25,26]$, the equilibrium moisture content was assumed to be zero. Thus, the moisture ratio was simplified according to Pala et al. [27] and Kingsly et al. [24] to:

$$
\mathrm{MR}=\frac{M}{M_{o}}
$$

The recorded moisture contents for each sample were then used to plot the drying curves.

Model prediction: Drying curves were fitted to three known mathematical models given in Table 1 . Regression analysis was used to select the model (based on goodness of fit) that best describes the drying data of the dehydrated coconut samples. Some of these models have been recently used by Doymaz [13,28], Demir et al. [29], Erenturk et al. [14], Friant et al. [30], Akpinar and Bicer [31], Sacilik and Elicin [12] and Vega et al. [32].

The correlation coefficient $\left(\mathrm{R}^{2}\right)$ and root mean square error (RMSE) were criteria used for selecting the best model equation that describes the drying curve. In order to evaluate the goodness of fit of the simulation given by the selected models, the mean relative error, $\% \mathrm{E}[33,34]$ and the reduced chi-square, $\chi^{2}$ were estimated [32-36].

$$
\begin{aligned}
\% \mathrm{E} & =\frac{100}{N} \sum_{i=1}^{N}\left[M R_{\exp i}-M R_{\text {prei }} / M R_{\exp i}\right] \\
\chi^{2} & =\sum_{i=1}^{N}\left(M R_{\exp i}-M R_{p r e i}\right) / N-Z
\end{aligned}
$$

Where $\mathrm{N}$, total number of observations, $\mathrm{Z}$, number of model parameters, $M R_{\exp i}$, experimental moisture ratio values and $M R_{\text {prei }}$, predicted moisture ratio values. It is generally considered that $\% \mathrm{E} \leq$ $10 \%$ gives a good fit $[34,37]$.

Effective moisture diffusivity: For the determination of the effective moisture diffusivity $\left(D_{e f f}\right)$, a mathematical model was used based on Fick's second law of diffusion which expresses a relationship between the moisture ratio and the effective moisture diffusivity, the solution for which was given by Crank [38] can be applicable for slab geometry by assuming uniform initial moisture distribution, constant diffusivity and negligible shrinkage is presented in Equation (11):

$$
\mathrm{MR}=\frac{8}{\pi^{2}} \exp \left[\frac{-D_{e f f}}{4 l^{2}} \pi^{2} t\right]
$$

Where $D_{\text {eff }}$ is effective moisture diffusivity $\left(\mathrm{m}^{2} / \mathrm{s}\right)$, $\mathrm{t}$, drying time and $l$, thickness (m)

Linear regression analysis was used to adjust the experimental data to Equation (11) which is the slope method [39].

\section{Results and Discussion}

\section{Osmotic dehydration}

Table 2 showed the results of the osmotic dehydration parameters. The water loss (WL) and weight reduction (WR) for the coconut chips increased as the sucrose concentration and osmotic processing temperature increased, respectively (i.e. the more concentrated osmotic dehydration solution and the higher temperature produce the higher water loss and weight reduction). Similar observations have been reported $[40,41]$. The water loss after the osmotic dehydration

\begin{tabular}{|lll|}
\hline No & Model Names & Model Equation \\
\hline a. & Newton & $M R=\exp (-k t)(6)$ \\
b. & Page & $M R=\exp \left(-k t^{n}\right)(7)$ \\
c. & Two-term exponential & $M R=a \exp (-k t)+(1-a) \exp (-k t)(8)$ \\
\hline
\end{tabular}

a, $n$, empirical constants; $k$, drying constant; t, drying time; MR, moisture ratio. Table 1: Typical models for thin layer drying [35]. 
Citation: Agarry SE, Aworanti OA (2012) Modelling the Drying Characteristics of Osmosised Coconut Strips at Constant Air Temperature. J Food Process Technol 3:151. doi:10.4172/2157-7110.1000151

Page 3 of 6

\begin{tabular}{|c|c|c|c|c|c|}
\hline $\begin{array}{l}\text { Osmotic Pretreatment } \\
\text { Conditions }\end{array}$ & $\begin{array}{c}\text { Sample } \\
\text { Weight (g) }\end{array}$ & $\begin{array}{c}\text { Moisture } \\
\text { Content } \\
(w / w) g / g\end{array}$ & $\begin{array}{c}\text { Weight Reduction (WR) } \\
\%\end{array}$ & $\underset{\%}{\text { Water Loss (WL) }}$ & $\begin{array}{c}\text { Sugar Gain } \\
\text { (SG) } \\
\%\end{array}$ \\
\hline $30^{\circ} \mathrm{C}-40 \%(w / w)$ & 30 & 0.343 & 6.33 & 9.15 & 4.9 \\
\hline $30^{\circ} \mathrm{C}-50 \%(w / w)$ & 30 & 0.280 & 12.67 & 16.55 & 6.0 \\
\hline $30^{\circ} \mathrm{C}-60 \%(w / w)$ & 30 & 0.250 & 15.67 & 19.92 & 6.3 \\
\hline $40^{\circ} \mathrm{C}-40 \%(w / w)$ & 30 & 0.300 & 10.67 & 14.20 & 5.4 \\
\hline $50^{\circ} \mathrm{C}-40 \%(w / w)$ & 30 & 0.270 & 13.67 & 17.69 & 6.2 \\
\hline Control (Non-osmosised) & 30 & 0.401 & - & - & - \\
\hline
\end{tabular}

Table 2: Osmotic dehydration parameters for coconut chips.

was in the order of $9-20 \%$, indicating that the proposal made for the possibility of pre-processing is viable.

\section{Oven drying}

The moisture ratio variations with drying times for each osmotic pretreatment condition of coconut chips (Figure 1) showed that moisture ratio decreases continuously with drying time for both the osmosised and control (non-osmosised) coconut samples. The continuous decrease in moisture ratio with time indicates that the internal mass transfer for coconut chips was governed by diffusion. This corroborates Piga et al. [42] and Kingsly et al. [24] observations. The osmotically pretreated samples took less time for drying than the untreated sample. Moreover, it was observed that as the osmotic agent (sucrose) concentration and pretreatment temperature increased, the hot air-drying time consequently decreased.

The influence of the osmotic pretreatment conditions drying rates of coconut chips (Figure 2,3) showed that the initial drying rates of the

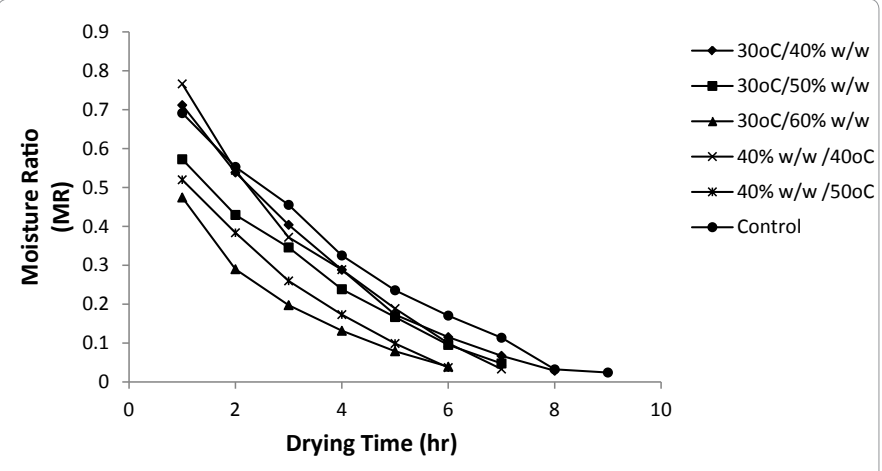

Figure 1: Variation of moisture ratio with drying time for both control (nonosmosised) and pre-osmosised coconut strip samples.

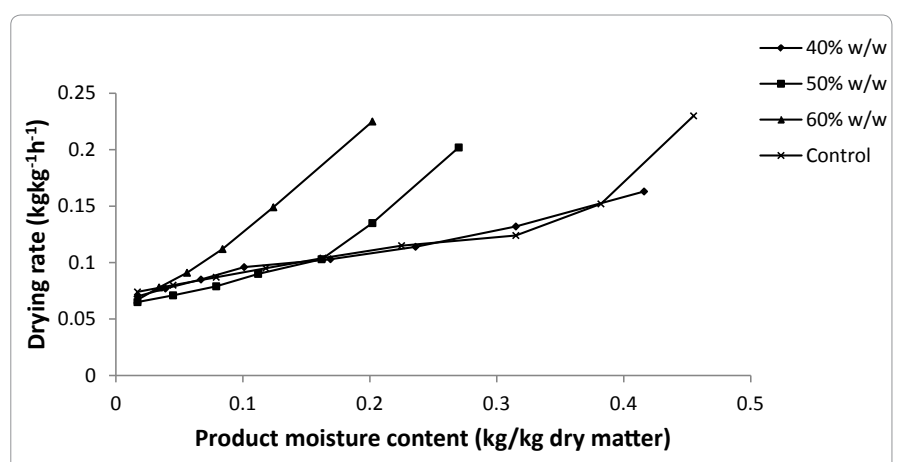

Figure 2: Drying curves of coconut osmotically pretreated at $30^{\circ} \mathrm{C}$ using different sucrose concentrations and air-dried at $60^{\circ} \mathrm{C}$.

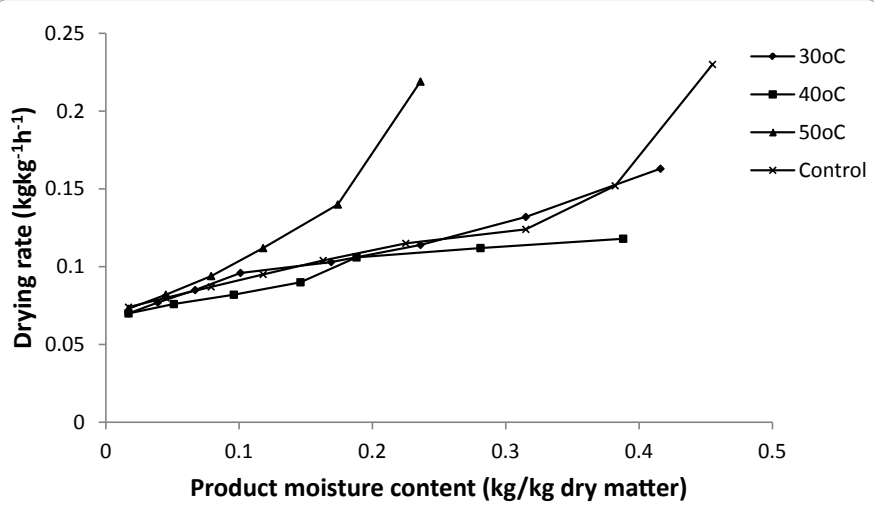

Figure 3: Drying curves of coconut osmotically pretreated at different temperatures using $40 \% \mathrm{w} / \mathrm{w}$ sucrose concentration and air-dried at $60^{\circ} \mathrm{C}$.

samples were generally high when the moisture content was highest and decreased rapidly until all samples showed similar rate after about $3 \mathrm{~h}$ of drying. This was due to the free moisture near the surface of the product being removed early in the process. Also, the initial drying rates decreased as the concentration of the osmotic agent (sucrose) solution increased. The initial drying rate was highest for the control (non-osmosised) sample. The high initial drying rate probably occurred because of its higher initial moisture content which were lower in the pre-osmosised samples (Table 2). These results corroborated Nieto et al. [10] wherein it was reported that osmotic pretreatment of mango with increased glucose concentration decreased the drying rate during hot air drying, and it is variant to Madamba [6] who reported that the osmotic pretreatment of coconut with sucrose solution had no significant effect on the convective drying phase.

Figure 3 showed the influence of osmotic pretreatment on the drying rates of coconut chips. It was observed that the initial drying rates decreased as the pretreatment temperature increased. The initial drying rate for the samples pretreated at $30^{\circ} \mathrm{C}$ was higher than that pretreated at $40^{\circ} \mathrm{C}$ and $50^{\circ} \mathrm{C}$, respectively. From Figure 2 and 3, it can be seen that the drying regime of coconut is characteristics of the falling rate period. The constant rate period was obviously not observed in both the control (non-osmosised) and pre- osmosised coconut samples because of the complex nature of the internal moisture movement mechanism.

\section{Drying models prediction}

Drying data for the different pre-osmosised and control (nonosmosised) coconut samples (Figure 1) were fitted to 3 different thin layer mathematical drying models (Equations (6)-(8)) listed in Table 1.

Using regression analysis, the parameters of the different models were determined, while values of $\mathrm{R}^{2}$ and RMSE were obtained as 
presented in Table 3. The most appropriate model(s) capable of predicting the drying data of non-osmosised and pre-osmosised coconut samples was selected on the basis of the highest $\mathrm{R}^{2}$ and lowest RMSE values. The page model had a good fitting of data in terms of $\mathrm{R}^{2}$ $>0.99$ and RMSE $<0.013$ for all the tested coconut samples.

Therefore, the page model is proposed as the best model describing the drying behaviour of non-osmosised and osmosised coconut samples dried at $60^{\circ} \mathrm{C}$. Similar observations have been reported for drying of red pepper [32,34,43]; tomato [36] and parsley leaves [44]. The estimated values for the page model parameters are summarized in Table 4 . The results shown in Table 4 shows that the osmotic variables (sucrose concentration and process temperature) used in the preprocessing of osmotic dehydration on prior to drying had a positive influence on the drying behaviour of coconut as described by the page model.

It is observed that the drying constant ' $k$ ' generally increased with increase in both the osmotic agent (sucrose) concentration and process temperature, respectively. While the empirical constant ' $n$ ' marginally decreased with increase in the osmotic agent concentration and marginally increase with increase in process temperature. The dependence of these model parameters on the osmotic variables can be represented through a linear regression relationship as given in the equations (12) and (13):

$$
\begin{aligned}
& k=0.2467+0.3493 \mathrm{x}_{1}+0.0023 \mathrm{x}_{2}\left(\mathrm{R}^{2}=0.98\right) \\
& n=0.6199-0.1392 \mathrm{x}_{1}+0.0030 \mathrm{x}_{2}\left(\mathrm{R}^{2}=0.98\right)
\end{aligned}
$$

It was also observed that the drying constant ' $k$ ' value for the osmosised samples were higher than of the non-osmosised sample. Thus, osmotic pretreatment increases the drying constant ' $k$ ' values during thermal air drying phase. The higher the ' $k$ ' value, lower is the drying time.

In order to mathematically evaluate the simulation, the mean relative error $(\% \mathrm{E})$, correlation coefficient $\left(\mathrm{R}^{2}\right)$, root mean square error (RMSE) and reduced chi-square $\left(\chi^{2}\right)$ were calculated from comparing the experimental moisture ratio and those given by the proposed model for the non-osmosised and pre-osmosised coconut samples dried at $60^{\circ} \mathrm{C}$. These results are shown in Table 4 . By using Equations (12) and (13) (page model), the moisture ratio variation during drying has been estimated. From Table 4, the $\% \mathrm{E}$ values were equal or below $10 \%$, the $\mathrm{R}^{2}$ value very high, RMSE and the reduced chi-square value $\left(\chi^{2}\right)$ were low for all osmosised and non-osmosised samples. Thus, the page model allowed an accurate simulation of the thermal drying curves of coconut for the whole range of osmotic process variables studied, exhibiting a high agreement between experimental and estimated (predicted) moisture ratio (Table 4).

\section{Effective moisture diffusivity}

The transport of water (or moisture transfer mechanism) during drying can be described by the Fick's diffusion model. The experimental drying curves obtained at drying temperature of $60^{\circ} \mathrm{C}$ for non-osmosised and pre-osmosised samples were adjusted to the Fick's diffusion equation (Equation (11)). The excellent linear adjustment to

\begin{tabular}{|c|c|c|c|c|c|c|}
\hline \multirow{2}{*}{$\begin{array}{l}\text { Osmotic Pretreatment conditions for } \\
\text { coconut samples }\end{array}$} & \multirow[b]{2}{*}{ Model Name } & \multicolumn{2}{|c|}{ Model } & Constants & \multirow[b]{2}{*}{$\mathbf{R}^{2}$} & \multirow[b]{2}{*}{ RMSE } \\
\hline & & $a$ & $k$ & $n$ & & \\
\hline \multirow[t]{3}{*}{$30^{\circ} \mathrm{C} / 40 \% \mathrm{w} / \mathrm{w}$} & Newton & - & 0.3083 & - & 0.7921 & 0.0684 \\
\hline & Page & - & 0.4663 & 0.6476 & 0.9992 & 0.0047 \\
\hline & Two-term exponential & 10.78 & 0.3083 & - & 0.7921 & 0.0762 \\
\hline \multirow[t]{3}{*}{$30^{\circ} \mathrm{C} / 50 \% \mathrm{w} / \mathrm{w}$} & Newton & - & 0.3272 & - & 0.7621 & 0.0692 \\
\hline & Page & - & 0.4795 & 0.6395 & 0.9921 & 0.0145 \\
\hline & Two-term exponential & 10.78 & 0.3276 & - & 0.7621 & 0.0799 \\
\hline \multirow[t]{3}{*}{$30^{\circ} \mathrm{C} / 60 \% \mathrm{w} / \mathrm{w}$} & Newton & - & 0.3847 & - & 0.7238 & 0.0699 \\
\hline & Page & - & 0.5326 & 0.6273 & 0.9999 & 0.00078 \\
\hline & Two- term exponential & 30.06 & 0.3847 & - & 0.7238 & 0.0855 \\
\hline \multirow[t]{3}{*}{$40^{\circ} \mathrm{C} / 40 \% \mathrm{w} / \mathrm{w}$} & Newton & - & 0.3471 & - & 0.8655 & 0.0568 \\
\hline & Page & - & 0.4730 & 0.6998 & 0.9997 & 0.00309 \\
\hline & Two- term exponential & 0.0650 & 0.3471 & - & 0.8655 & 0.0656 \\
\hline \multirow[t]{3}{*}{$50^{\circ} \mathrm{C} / 40 \% \mathrm{w} / \mathrm{w}$} & Newton & - & 0.3936 & - & 0.8667 & 0.0545 \\
\hline & Page & - & 0.5071 & 0.7073 & 0.9997 & 0.0034 \\
\hline & Two-term exponential & -9.935 & 0.3936 & - & 0.8667 & 0.0667 \\
\hline \multirow[t]{3}{*}{ Control (Non- osmosised) } & Newton & - & 0.246 & - & 0.9166 & 0.0508 \\
\hline & Page & - & 0.3568 & 0.7594 & 0.9949 & 0.0136 \\
\hline & Two-term exponential & -59.22 & 0.246 & - & 0.9166 & 0.0549 \\
\hline
\end{tabular}
this equation with correlation coefficient of $99 \%$ show that drying of

\begin{tabular}{|c|c|c|c|c|c|c|}
\hline Osmotic Pretreatment & $k$ & $n$ & $\% \mathrm{E}$ & RMSE & $x^{2}$ & $\mathbf{R}^{2}$ \\
\hline $30^{\circ} \mathrm{C} / 40 \% \mathrm{w} / \mathrm{w}$ & 0.4663 & 0.6476 & 11.4 & 0.0415 & 0.00259 & 0.95 \\
\hline $30^{\circ} \mathrm{C} / 50 \% \mathrm{w} / \mathrm{w}$ & 0.4795 & 0.6395 & 1.82 & 0.0138 & 0.00032 & 0.98 \\
\hline $30^{\circ} \mathrm{C} / 60 \% \mathrm{w} / \mathrm{w}$ & 0.5326 & 0.6273 & 1.02 & 0.0038 & 0.00003 & 0.99 \\
\hline $40^{\circ} \mathrm{C} / 40 \% \mathrm{w} / \mathrm{w}$ & 0.4730 & 0.6998 & 0.70 & 0.0041 & 0.000027 & 0.99 \\
\hline $50^{\circ} \mathrm{C} / 40 \% \mathrm{w} / \mathrm{w}$ & 0.5071 & 0.7073 & 0.36 & 0.0032 & 0.000021 & 0.99 \\
\hline Control(Non-osmosised) & 0.3568 & 0.7594 & 2.99 & 0.0163 & 0.000355 & 0.97 \\
\hline
\end{tabular}

Table 3: Drying model constants and goodness of fit parameters for coconut samples.

Table 4: Summary of the values of page model parameters together with the mean relative error $(\% \mathrm{E})$ reduced chi-square $\left(\mathrm{X}^{2}\right)$, root mean square error (RMSE) and correlation coefficient $\left(R^{2}\right)$ for the drying of coconut. 


\begin{tabular}{|l|l|l|}
\hline Osmotic Pretreatment & $\left.\boldsymbol{D}_{\text {eff }} \mathbf{X} \mathbf{1 0}^{-10} \mathbf{( m}^{2} / \mathbf{s}\right)$ & $\mathbf{R}^{\mathbf{2}}$ \\
\hline $30^{\circ} \mathrm{C} / 40 \% \mathrm{w} / \mathrm{w}$ & 5.74 & 0.9932 \\
\hline $30^{\circ} \mathrm{C} / 50 \% \mathrm{w} / \mathrm{w}$ & 6.26 & 0.9997 \\
\hline $30^{\circ} \mathrm{C} / 60 \% \mathrm{w} / \mathrm{w}$ & 6.91 & 0.9952 \\
\hline $40^{\circ} \mathrm{C} / 40 \% \mathrm{w} / \mathrm{w}$ & 6.88 & 0.9943 \\
\hline $50^{\circ} \mathrm{C} / 40 \% \mathrm{w} / \mathrm{w}$ & 7.88 & 0.9955 \\
\hline Control (Non-osmosised) & 5.44 & 0.9920 \\
\hline
\end{tabular}

Table 5: Values of the effective moisture diffusivity of coconut dried at $60^{\circ} \mathrm{C}$.

coconut slices is well represented by the diffusion model proposed by Fick, and this enable the calculation of the effective moisture diffusivity $\left(D_{e f f}\right)$ for both the non-osmosised and pre-osmosised samples. The results showed that the effective moisture diffusivity of pre-osmosised coconut slices ranged from 5.74 to $7.88 \times 10^{-10} \mathrm{~m}^{2} / \mathrm{s}$, while that for non-osmosised coconut sample is $5.44 \times 10^{-10} \mathrm{~m}^{2} / \mathrm{s}$. These values were found to be within the general range $10^{-11}-10^{-9} \mathrm{~m}^{2} / \mathrm{s}$ for drying of food materials $[6,12,20,36,45-47]$.

Also, it could be observed from Table 5, that the effective moisture diffusivity increased with increase in the osmotic predrying process variables (sucrose concentration and pretreatment temperature) used in pre-processing of osmotic dehydration prior to drying. The values for the pre-osmosised samples are higher than that of non-osmosised sample. Thus, osmotic pretreatment increased the effective moisture diffusivity. This is in contrast to the observation of Nieto et al. [10]. These workers reported that osmotic pretreatment strongly decreased the effective moisture diffusivity of mango dried at $60^{\circ} \mathrm{C}$. They adduced glucose uptake during the impregnation step and starch gelatinization as possible reasons for this observation.

\section{Conclusion}

Osmotic dehydration reduces considerably the drying rate and drying time of coconut samples due to loss of the initial water content. The osmotic dehydration is a pre condition which had a significant influence on the thermal air drying behaviour of coconut. The proposed thin layer drying model of page provides an adequate preliminary description stage for the drying behaviour of coconut and this could represent a significant tool for engineering purposes. The Fick's diffusion model showed a better adjustment to the experimental drying data which allowed the determination of the effective moisture diffusivity. Osmotic pretreatment increased the effective moisture diffusivity.

\section{References}

1. Sigge GO, Hansmann CF, Joubert E (1998) Effect of temperature and relative humidity on the drying rates and drying times of green bell papers (capsicum annum L). Drying Technology 16: 1703-1714.

2. Horner WFA (1993) Drying: chemical changes in: Macrae R, Robinson RK, Sadler MJ (Eds) Encyclopedia of Food Science, Food Technology and Nutrition, Academic Press, London, 1485-1489.

3. Sankat CK, Castaigne F, Maharaj R (1996) The air drying behaviour of fresh and osmotically dehydrated banana slices. International Journal of Food science and Technology 31: 123-135.

4. Rahman MS, Lamb J (1990) Osmotic dehydration of pineapple. Journal of Food Science and Technology 27: 150-152.

5. Karathanos VT, Kostaropoulos AE, Saravacos GD (1995) Air drying kinetics of osmotically dehydrated fruits. Drying Technology 13: 1503-1521.

6. Madamba PS (2003) Thin layer drying models for osmotically pre-dried young coconut. Drying Technology 21: 1759-1780.
7. Panagiotou NM, Karathanos VT, Maroulis ZB (1998) Mars transfer modeling of the osmotic dehydration of some fruits. International Journal of Food science and Technology 33:267-284.

8. Ozen BF, Dock LL, Ozdemir M, Floros JD (2002) Processing factors affecting the osmotic dehydration of diced green peppers. International Journal of Food science and Technology 37: 497-502.

9. Cunha LM, Oliveira FAR, Aboim AP, Frias JM, Pinheiro-Torres A (2001) Stochastic dehydration and improved parameter estimation. International Journal of Food science and Technology 36: 253-262.

10. Nieto A, Castro MA, Alzamora SM (2001) Kinetics of moisture transfer during air drying of blanched and/or osmotically dehydrated mango. Journal of Food Engineering 50: 175-185.

11. Garcia CC, Mauro MA, Kimura M (2007) Kinetics of osmotic dehydration and air drying of pumpkins (Cucurbita moschata). Journal of Food Engineering 82 284-291.

12. Sacilik K, Elicin AK (2006) The thin layer drying characteristics of organic apple slices. Journal of Food Engineering 73: 281-289.

13. Doymaz I (2004) Convective air drying characteristics of thin layer carrots Journal of Food Engineering 61: 359-364.

14. Erenturk S, Gulaboglu MS, Gultekin S (2004) The thin layer drying characteristics of rosehip. Biosystems Engineering 89: 159-166.

15. Goyal RK, Kingsly ARP, Manikantan MR, llyas SM (2006) Thin layer drying kinetics of raw mango slices. Biosystems Engineering 95: 43-49.

16. Niamnuy C, Devahastin S (2005) Drying kinetics and quality of coconut dried in a fluidized bed dryer. Journal of Food Engineering 66: 267-271.

17. Madhiyanon T, Phila A, Soponronnarit S (2009) Models of fluidized bed drying for thin-layer chopped coconut. Applied Thermal Engineering 29: 2849-2854.

18. FAO (2010) Food and Agricultural Organization of the United Nation. Economic and Social Department. Statistic Division.

19. Uwubanmwen IO, Nwawe CN, Okere RA, Dada M, Eseigbe E (2011) Harnessing the potentials of the coconut palm in the Nigerian economy. World Journal of Agricultural Sciences 7: 684-691.

20. Dandamrongrak R, Mason R, Young G (2003) The effect of pretreatments on the drying rate and quality of dried bananas. International Journal of Food science and Technology 38: 877-882.

21. Agarry SE, Durojaiye AO, Afolabi TJ (2005) Effects of pretreatment on the drying rates and drying time of potato. Journal of Food Technology 3: 361-364

22. AOAC (1995) Official methods of Analysis Washington, DC: Association of official Analytical chemists.

23. Karathanos VT, Belessiotis VG (1999) Application of thin-layer equation to drying data of fresh and semi-dried fruits. Journal of Agricultural Engineering Research 74: 355-361.

24. Kingsly RP, Goyal RK, Mani Kantan MR, llyas SM (2007) Effects of pretreatments and drying air temperature on drying behaviour of peach slice. International Journal of Food science and Technology 42: 65-69.

25. Togrul IT, Pehlivan D (2004) Modeling of thin layer drying kinetics of some fruits under open air sun drying process. Journal of Food Engineering 65: 413-425.

26. Waewsak J, Chindaruksa S, Punlek C (2006) A mathematical modeling study of hot air drying for some agricultural products. Thammasat Int J Sci Tech 11 : $14-20$.

27. Pala M, Mahmutoglu T, Saygi B (1996) Effects of pretreatments on the quality of open air and solar dried apricots. Food 40: 137-141.

28. Doymaz I (2004) Pretreatment effect on sundrying of mulberry fruits (Morus alba L.). Journal of Food Engineering 65: 205-209.

29. Demir V, Gunhan T, Yagcioglu AK, Degirmencioglu A (2004) Mathematica modeling and the determination of some quality parameters of air-dried bay leaves. Biosystems Engineering 88: 325-335.

30. Friant NR, Marks BP, Bakker-Arkema FW (2004) Drying rate of ear corn Transactions of the ASAE 47: 1605-1610. 
Citation: Agarry SE, Aworanti OA (2012) Modelling the Drying Characteristics of Osmosised Coconut Strips at Constant Air Temperature. J Food Process Technol 3:151. doi:10.4172/2157-7110.1000151

Page 6 of 6

31. Akpinar EK, Bicer, Y (2005) Modeling of the drying of egg plants in thin-layers. International Journal of Food science Technology 40: 273-281.

32. Vega A, Fito P, Andres A, Lemus R (2007) Mathematical modeling of hot air drying kinetics of red bell pepper (var. lamuyo). Journal of Food Engineering79: 1460-1466.

33. Nguyen TA, Verboven P, Daudin JD, Nicolai B (2004) Measurement and modeling of water sorption isotherms of "conference" pear flesh tissue in the high humidity range. Postharvest Biol Technol 33: 229-241.

34. Simal S, Garau C, Femenia A, Rossello C (2005) Drying of red pepper (Capsicum annum): water desorption and quality. International Journal of Food Engineering 1: 1-12.

35. Ertekin C, Yaldiz O (2004) Drying of egg plant and selection of a suitable thin layer drying model. Journal of Food Engineering 63: 349-359.

36. Doymaz I (2007) Air drying characteristics of tomatoes. Journal of Food Engineering 78: 1291-1297.

37. Park KJ, Vohnikova Z, Reis Brod FP (2002) Evaluation of drying parameters and desorption isotherms of garden mint leaves (Mentha crispa L). Journal of Food Engineering 51: 193-199.

38. Crank J (1975) The mathematics of diffusion. (2nd ed.), Oxford, London.

39. Feng $\mathrm{H}$, Tang J, Dixon-Warren St (2000) Determination of moisture diffusivity of red delicious apple tissues by thermogravimetric analysis. Drying Technology 18: 1183-1199
40. Heng K, Guilbert S, cuq JL (1990) Osmotic dehydration of papaya: influence of process variables on the product quality. Sciences Des Aliments 10: 831-848.

41. Vial C, Guilbert S, Cuq JL (1991) Osmotic dehydration of kiwi fruits: influence of process variables on the color and ascorbic acid content. Sciences Des Aliments 11: 63-84

42. Piga A, Pinna I, Ozer KB, Agabbio M, Aksoy U (2004) Hot air dehydration of figs (Ficus carica L.): drying kinetics and quality loss. International Journal of Food Science Technology 39: 793-799.

43. Doymaz I, Pala M (2002) Hot air drying characteristics of red pepper. Journal of Food Engineering 55: 331-335.

44. Akpinar EK, Bicer Y, Cetinkaya F (2006) Modeling of thin layer drying of parsley leaves in a convective dryer and under open sun. Journal of Food Engineering75: 308-315.

45. Dandamrongrak R, Young G, Mason R (2002) Evaluation of various pretreatments for the dehydration of banana and selection of suitable drying models. Journal of Food Engineering 55: 139-146.

46. Kaleemullah S, Kailappan, R (2006) mode thing of thin layer drying kinetics of red chilies. Journal of Food Engineering 76: 531-537.

47. Jain D, Pathare PB (2007) Study the drying Kinetics of open sun drying of fish Journal of Food Engineering 78: 1325-1319. 